\title{
EDITORIAL
}

\section{Qual o papel da estética na resistência à violência?}

RuMoRes, revista científica dedicada aos estudos de comunicação, linguagem e mídias propõe, neste número, indagar como as diversas produções e práticas midiáticas podem nos ajudar a resistir contra violências do passado e do presente. Os artigos publicados nesta $29^{a}$ edição nos lembram do percurso pela memória como construção, como valor, como narrativa que nos erige e fornece possibilidade de enfrentamentos. Codificar, nessas análises críticas, o resgate de uma memória midiática devolve mobilidade à construção e desconstrução de imaginários e, com isso, não se pretende um dizer sem efeitos, mas, ao contrário, pronto para a ação e a interferência social.

Assim é que publicamos o Dossiê "Mídia e memória: visibilidades e resistências", organizado por Jennifer Jane Serra e Rosana de Lima Soares, com artigos que abordam os efeitos de sentido muito presentes em produções midiáticas que lidam com a memória e seu par - o esquecimento -, em um pacto pela resistência política. Apontamos especialmente tal resistência na América Latina, em que as teorias dedicadas a discutir e identificar subjetividades chegam pelas brechas: não fazem outra coisa que desviarem brilhantemente o caminho para proporem uma relação profícua entre o individual e o coletivo, entre o ficcional e o factual, sendo férteis para lançar, em nossos territórios, novas perspectivas sobre como pensar as diversidades. Aportes teóricos e produções históricas se mesclam a possibilidades de renovação numa materialidade em que passado, presente e futuro estão condensados.

No corpo da edição, por sua vez, temos um primeiro conjunto de artigos que lidam com imagens de diferentes tipos de violência, aquelas do racismo, as de gênero, as geracionais, as desterritorializadas. Ismail Xavier, em "Inquietações 
da adolescência: da redoma da Casa Grande ao mergulho no tempo presente da cidade", analisa o filme Casa Grande, de Felipe Barbosa (2014), buscando a repetição de processos de exclusão arraigados na sociedade brasileira e revividos na trajetória da vida de um adolescente que começa a ganhar a cidade do Rio de Janeiro. Mayra Rodrigues Gomes, em "Os nomes da violência contra as mulheres: das narrativas no jornalismo", recupera como o jornalismo está reportando casos de violência contra as mulheres ao refletir os altos índices observados já em 2018 e que podemos extrapolar hoje em tempos pandêmicos. "Micro-história italiana e jornalismo em Expectativa de vida: vinte anos e Mães vivas de uma geração morta", de Francisco Aquinei Timóteo Queirós, parte da prática jornalística de Eliane Brum no livro O olho da rua, observando a entrada de sujeitos comuns nas narrativas e como seus relatos importam. E, em "Complexidade e compreensão em reportagens sobre a crise humanitária: a narrativa jornalística de Paulo Moura", Mauro de Souza Ventura e Tayane Aidar Abib procuram caminhos para testemunhar a crise de refugiados analisando o trabalho de Paulo Moura em Passaporte para o céu (2005).

A resistência pode também significar poéticas e políticas latentes, que se condensam no presente para dar curso a narrativas que renovam as possibilidades técnicas e históricas nas mídias. Eduardo Vicente, em "A grande novidade do rádio na internet é o... áudio!" recupera certa história construída sobre o rádio para encontrar nela mesma as respostas para o entendimento das possibilidades expressivas mais atuais das mídias sonoras e seus usos sociais, como no podcasting. Mônica Rodrigues Nunes e Ana Paula Silva Ladeira Costa, em "Oferta de produção audiovisual durante a pandemia da Covid-19: estratégias e adaptações da Rede Globo e Netflix", recuperam os acordos que tornaram possíveis a inserção da plataforma no Brasil e debatem, a partir dela, sobre a lógica do excesso e da letargia, do internacional e do local, e suas interações no campo da produção e da recepção.

Em "A poética da entrevista no documentário O país de São Saruê", José Francisco Serafim e Renato Meira dos Santos Filho analisam o audiovisual de 1971, dirigido pelo cineasta paraibano Vladimir Carvalho, julgando o reducionismo sobre as 
falas dos entrevistados e a minimização de opiniões divergentes. Gabriel Henrique de Paula Carneiro, em "Estranho encontro (1958) e o estilo nascente de Walter Hugo Khouri", investiga se o estilo do diretor já estaria presente em seu segundo documentário enquanto modernidade e composição de atmosfera. Em "Maldito bem dito, bendito mal dito: construções discursivas a partir da trajetória de Itamar Assumpção", Larissa Caldeira e Jorge Cardoso Filho discutem relações de poder desenhadas por regimes de verdade e questionam se articulações estéticopolíticas dependem, de fato, de temporalidades e historicidades.

Atravessando as aparentes separações entre estética e política, técnica e conteúdo, realidade e ficção, a aposta dos artigos desta edição - e que reforçamos é a de que o combate aos variados tipos de violência se faz (também e especialmente) a partir de imaginários que possam sonhar outros mundos quando a realidade se mostra sombria. Que haja repertório para todas e todos desafiarmos os futuros próximos e transformarmos os distantes por meio de melhores projeções do hoje nas mídias. Boas leituras!

MidiAto - Grupo de Estudos de Linguagem: Práticas Midiáticas junho de 2021 